\title{
Management of wastewater trough theatre
}

\author{
Kristina Tihomirova, Linda Mezule
}

Department of Water Engineering and Technology, Riga Technical University, Latvia.

\begin{abstract}
Compulsory study course on wastewater treatment and sewage systems contains lectures, classroom calculations, technical project and laboratory practicum. The course is addressing not only the developing skills in wastewater treatment technologies but also provides preparation of professionals that can communicate with institutions involved in water and wastewater sector. Over the years it has been observed that even after receiving the most sophisticated knowledge and highest markings, students often lack skills in practical communication with industry and implementation of theoretical knowledge in praxis. Here we describe studentcentred teaching method that is based on the activities that are similar to theatre and allow: (i) the teacher to find and understand the weaker places in student knowledge gained during the semester; (ii) the students to form professional skills during the active communication with colleagues and mentors from industry. The students work in several groups "INDUSTRY", "MUNICIPALITY" and EXPERTS", try to find better solution for industrial sewage treatment and cooperation model with the municipality and present their results. After 2 years of the modernisation and adjustment, the training course has created an interest not only from student side but also from the industry representatives that are interested in communication with the new specialists and develop strong contacts with the university.
\end{abstract}

Keywords: student-centred teaching; team work; wastewater management. 


\section{Introduction}

Conventional opinion is that a teacher is a person who helps others to acquire knowledge, competences or values (NGSS Lead States, 2013). From one side this role may be taken by anyone, but not anyone can acquire competence and to grow interest for the field. There are several methodologies that are based on the training through the activities or games. This approach is regarded as a modern interactive method of training, which should encourage interest in the selected profession (Yakovleva\&Yakovlev, 2014). The two most often mentioned models in literature sources are teacher-centred method and student-centred approach (Joyce et al., 2014, Glater et al., 2016, Schreurs\&Dumbraveanu, 2014). Teacher`s choice of selected work model depends on their philosophy, subject area and other factors (Garret, 2008, Joyce et al., 2014). The teacher is the main authority figure in teachercentred models (Alam, 2013; Gill, 2013, Glater et al., 2016). Students receive information and give evaluation through the tests and exams. In student-centred approach, both teacher and students play active role. This model provides more informal environment and students' work through various projects, presentations of ideas or discussions. Nevertheless, implementation of different technologies, such as, computers, interactive whiteboard, Internet or some specific technological models in any of the two models in the study process makes it more interesting and modern.

Institute of Heat, Gas and Water technologies (SGUTI) is a part of Faculty of Civil Engineering at Riga Technical University (state founded non-profit and accredited higher educational establishment of the Republic of Latvia) and consists of two departments: 1) Heat Engineering and Technology and 2) Water Engineering and Technology. Both provide all level higher education and carry out research in the field of heating, ventilation, airconditioning, water and wastewater treatment systems, water distribution network and sewage collection system.

Compulsory study course on wastewater treatment and sewage systems (course number BUK310) in SGUTI includes lectures, classroom calculations, technical project and laboratory practicum. In addition to the development of skills in wastewater treatment technologies, the course also:

1) addresses the main problematic sources and contents of the industrial effluents and their possible impacts on conventional treatment process at municipal WWTPs;

2) identifies the existing practices, challenges in institutional capacity, stakeholder cooperation, management models and legislative implementation regarding water utilities, industrial companies, permitting and legislative authorities;

3) development, demonstration and evaluation of new cooperation, management and working models on local level between the water utility, industrial companies and monitoring authorities. 
It is aimed that BUK310 training will prepare professionals that can communicate with participating institutions of water utilities, industrial companies, municipal and regional authorities for more efficient process control, management and cooperation models, potential technologies and economic, environmental and social incentives. However, during the several years of work with students, it was observed, that students have a low understanding and evaluation capabilities of gained results after the courses. Thus, a modification in the existing teaching method was made to grow practical understanding, skills and knowledge in the field of wastewater management through the communication with professional mentors and representatives from relevant industries.

\section{Methodology}

The introduced teaching method is aimed to develop skills and knowledge in the field of wastewater management. This method is based on the activities that are similar to theatre and allow: (i) the teacher to find and understand the gaps in student`s knowledge gained during the semester; (ii) the students to generate professional skills during the active communication with colleges and mentors. There are several steps before organization of training though the theatre:

1. Learning of the basic study material throughout the semester (wastewater quality parameters, treatment technologies, sewage system, legalisation rules);

2. Professional excursions to different WWTP aimed to compare theory and reality, to see the difference in real systems;

3. Wastewater treatment plant (WWTP) and sewage system design and construction in the specific IT program.

For efficient performance, it is necessary to prepare a scenario and to find active mentors from the industry. It is important to remember that the training can take place for several hours (4-6 academic hours) or full day, depending on the scenario and persons involved. Usually 1-2 mentors are invited for a 20-person group of students, the responsible staff of training also gets involved as a mentor. It is recommended to use a room, where students can create a workplace for the teams themselves. Everyday materials, such as coloured markers, whiteboards, paper, are essential. Till some extent catering (drinking water, tea, sweats) is also essential to make the training day more casual and interesting.

Within this article one example of a scenario for 4 academic hour work with a group of 19 students and 2 mentors from the industry is described. The theme was tested in 2018 autumn semester. 


\subsection{Introduction for training}

The teacher informs the students of training goals, hopes regarding activities and introduces to 3 mentors (2 representatives from industries and lecturer). Students form work groups:

1. 3 groups of 4 persons will represent industry (food, feed production or other);

2. 1 group of 4 persons will represent municipality of a small fast growing town in Latvia (relevant to any other country in EU);

3. 3 students will represent experts in the field of wastewater technologies and legalisation.

One mentor will coordinate the work of "INDUSRY" student teams, other "MUNICIPALITY”, third mentor - "EXPERTS”.

\subsection{Order of the training}

The invited mentors start the training from the presentation about the represented industry: what kind and amount of products their produce, amount of wastewater, how successful is the communication between their industry and municipalities in their district. If mentors represent municipality, they present wastewater collection and treatment system, its scheme, loads and restrictions for the collected wastewater. Presentation time is limited for 15 minutes per mentor.

The teacher informs the students about the goals for each team (time limit 15 minutes):

"INDUSTRY" team should choose the type of production (example, cheese, milk, pharmacy, chemical industry). After a discussion time of 45 minutes, each team should present their selected industry. They present wastewater quality parameters and their decision about the wastewater management, including the following points: is it planned to build a WWTP to treat the industrial wastewater; will a pre-treatment stage be included and what kind of cooperation will be made with the municipality; or is it planned to have wastewater discharge into the sewage system of municipality.

"MUNICIPALITY" team should present their district and specific WWTP system and restrictions for the industrial wastewater with the clarification why these restrictions are made.

"EXPERTS" one per "INDUSTRY" team should communicate with the industry and municipality and try to help to find better solution for wastewater management.

During the discussion time the best technology for industrial wastewater pre-treatment should be selected from the perspective of all involved parties. The students can use all Internet resources, course materials to find wastewater characteristic parameters for chosen type of industry and systems used for treatment of this specific type wastewater. All teams can take consultations from mentors. 
Final part of the training is the presentation of the developed results, discussion aimed to setting up guidelines for a better management of industrial wastewater and conclusions.

To present the results of the discussion students can use all available equipment (computers, interactive whiteboard or board with paper and marker). It is important for participants to divide roles to present the work could be by each member of the group.
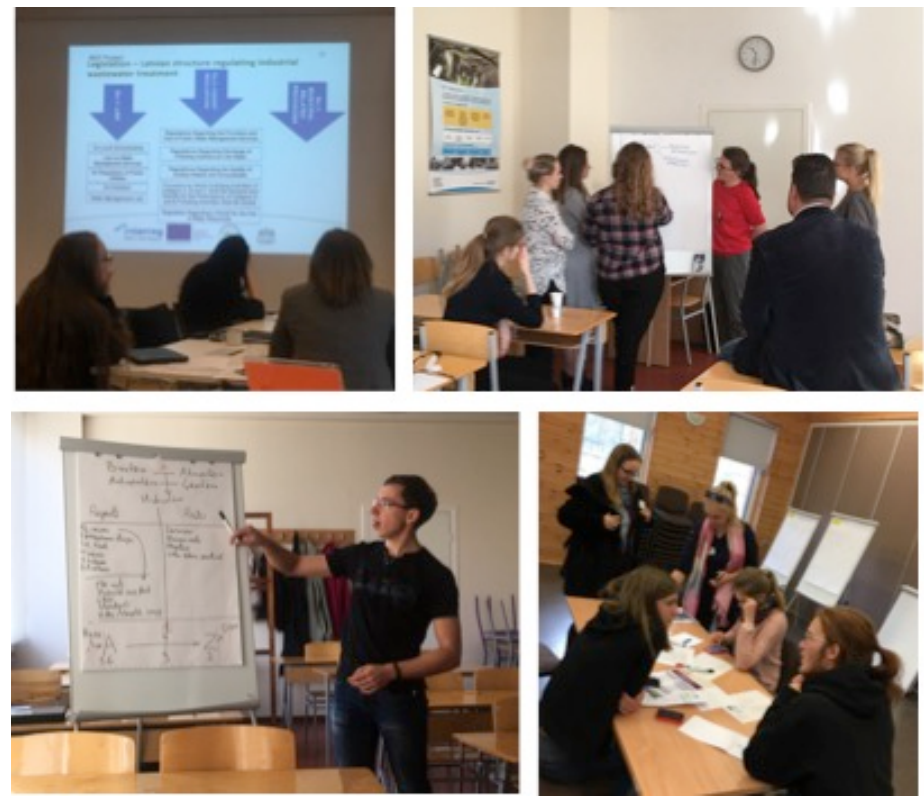

Figure 1. Example of discussion process and presentations in class. Photo by Tihomirova (2018).

\section{Discussion}

Several years of practical and academic experience allows to recognize that the progress in water and wastewater management field depends on communication skills of all representatives that are going to cooperate. It is important to not only understand the legislation part of wastewater management or how the industrial or municipal wastewater treatment works, but also to understand the needs and resources to achieve an improved cooperation result. The practical application of knowledge gained during the theoretical studies should be trained in the universities.

During the study of BUK310 course on wastewater treatment and sewage systems (Table 1) students acquire skills via lectures, calculations, project and laboratory work. After course finalisation they are expected to have knowledge in wastewater treatment technologies, understand the main problematic sources and contents of the industrial effluents and their possible impacts on conventional treatment process at municipal WWTPs. 
The modernised course with the workshop "Management of wastewater trough theatre" aids in development of communication and critical thinking skills for new specialists with the help of mentors from the specific field. Even if these professionals are not trained lecturers, their practical knowledge supports the theory learned during the classes and complements practical works (Table 1).

Table 1. Comparison of conventional and modernised teaching approach.

\begin{tabular}{|c|c|c|c|}
\hline & \multicolumn{2}{|c|}{ Course } & \multirow[b]{2}{*}{ Gain knowledge } \\
\hline & Compulsory & Modernised & \\
\hline Lectures & + & + & $\begin{array}{c}\text { Basics of wastewater treatment } \\
\text { proceses and legalization }\end{array}$ \\
\hline Calculations & + & + & $\begin{array}{c}\text { Basics of mechanisms of } \\
\text { proceses }\end{array}$ \\
\hline Course work & + & + & $\begin{array}{c}\text { Engineering calculations for full } \\
\text { cycle of wastewater treatment } \\
\text { process }\end{array}$ \\
\hline \multirow[t]{2}{*}{ Technical visit } & o & + & $\begin{array}{l}\text { Comparison of real system with } \\
\text { gained basic knowledge }\end{array}$ \\
\hline & & & Communication skills \\
\hline \multirow[t]{4}{*}{ Workshop } & - & + & Communication skills \\
\hline & & & Critical thinking skills \\
\hline & & & Team work \\
\hline & & & Finding and evaluating research \\
\hline \multirow{2}{*}{$\begin{array}{c}\text { Expert } \\
\text { consultation }\end{array}$} & - & + & Communication skills \\
\hline & & & Industry perceptive \\
\hline Examination & + & + & \\
\hline
\end{tabular}

o - optional

The modernised course of wastewater treatment and sewage systems can be comparable with Problem-Based Learning (PBL) teaching method, that promotes the development of critical thinking skills, problem-solving abilities, communication skills and promotes working in groups, individual finding and evaluation of research materials (Duch et al, 2001). In this case the students are the active participant in the learning process rather that a passive receiver of information - they analyse a given problem, identify and integrate the obtained knowledge under the mentor guidance (Kleger and Hurren, 2011). 
The tested approach "Management of wastewater trough theatre” includes not only training of communication or teaches how to ask the right questions and negotiate until the joint decision on the technology to be implemented has been made but also facilitates working in groups. "EXPERTS" team detects flaws in the used technologies and finds a better way to improve the technologies, evaluates resources and also tries to summarize the recommendations for collaboration among "INDUSRY” and "MUNICIPALITY” partners.

The described methodology can be used to educate engineers in various fields. It will help to develop communication skills of specialists with strong mathematical education. Therefore, with this methodology more effective modernization of the field will be made as result of correct communication.

\section{Conclusions}

"Management of wastewater trough theatre" is based on the activities that are similar to theatre and allow the teacher to find and understand weak places in student`s knowledge gained during the semester in order to fill the gaps. The students acquire professional skills during the active communication with colleagues and mentors from the respective industry. After two years since the modernisation has been introduced, SGUTI BUK310 course has created an interest not only from the students who gain more practical understanding about the requirements behind wastewater treatment but also from the representatives of the industry that are interested in communication with the new specialists and develop strong contacts with the university.

\section{Acknowledgments}

This work has been supported by the INTERREG Baltic Sea region program project BEST (Better Efficiency for Industrial Sewage Treatment, \#R054).

\section{References}

Alam, M. (2013). Banking Model of Education in Teacher-Centered Class: A Critical Assessment. Research on Humanities and Social Sciences, 3 (15), 27-31. ISSN 22222863.

Concordia University-Portland. (2018). Which is Best: Teacher-Centered or StudentCentered Education? Retrieved Jan. 27, 2019, from https://education.cuportland.edu/blog/classroom-resources/which-is-best-teacher-centered-or-studentcentered-education/

Duch, B. J., Groh, S. E, Allen, D. E. (Eds.). (2001). The power of problem-based learning. Sterling, VA: Stylus. 
Garret, T. (2008). Student-Centered and Teacher-Centered Classroom management: a Case Study of Three Elementary Teachers. Journal of Classroom Interaction, 43(1), 34-47. ISSN 0749-4025.

Gill, E. (2013). What is Your Teaching Style? 5 Effective Teaching Methods for Your Classroom. Retrieved Jan. 5, 2019, from https://education.cuportland.edu/blog/classroom-resources/5-types-of-classroom-teaching-styles/

Glatter, H., Deruy, E., Wong, A. (2016) Disrupting the One-Teacher Standard. Retrieved Jan. 27, 2019, from https://www.theatlantic.com/education/archive/2016/09/disruptingthe-one-teacher-model/498197/

Joyce, B.R., Weil, M., Calhoun, E. (2014) Models of teaching (9th ed.). Boston, MA: Pearson.

Klegeris, A., Hurren, H. (2011). Impact of problem-based learning in a large classroom setting:student perception and problem-solving skills. Advances in Physiology Education, 35, 408-415. doi: 10.1152/advan.00046.2011.

National Research Council (2013). Standards for Professional Development for Teachers of Science (Chapter 4). Next Generation Science Standards: For States, By States. Washington, DC: The National Academies Press, 55-76. doi.org/10.17226/18290.

Schreurs, J., Dumbraveanu, R. (2014). A Shift from Teacher Centered to Learner Centered Approach. International Journal of Engineering Pedagogy, 4(3), 3395-3402. doi: 10.3991/ijep.v4i3.3395

Yakovleva, O., Yakovlev, E. (2014). Interactive teaching methods in contemporary higher education. Pacific Science review, 16(2), 75-80. doi.org/10.1016/j.pscr.2014.08.016 